\title{
To Act in Concert (1821-22)
}

I N A MASTERful STUDY of the emergence of the modern world, C. A. Bayly describes a world crisis of $1780-1820$, which originated in "a growing imbalance between the perceived military needs of states and their financial capacity." Even more consequential than the material crisis, according to Bayly, was the underlying social crisis caused by economic conflict and a culture of opposition that "had made people more skeptical of, and hostile to, established authority." Both the American and French revolutions highlighted the power of popular rebellion and the acceptance of war as a tool of modern progress. Napoleon's empire likewise justified military conquest under the mantle of progressive reform. With this history in mind, the peacemakers of 18 I $_{4}-18$ and the European governments established, reestablished, or simply maintained in the aftermath of Napoleon's defeat appear less the harbingers of restoration or recuperation and more the representatives of "a moderating discourse of law, religion, or polity" that held out the hope of enlightened reform and peaceful advancement. ${ }^{1}$ Like reform-minded leaders in other countries, Emperor Alexander I and his diplomatic agents saw in the transactions of Paris, Vienna, and Aix-la-Chapelle the political framework and legal foundations for peaceful order in Europe. In the Treaty of I4/26 September I8I5 (the Holy Alliance), described by recent Russian scholarship as a form of Christian cosmopolitanism, they also identified the means to end war and unite the peoples of Europe regardless of national and religious affiliations. ${ }^{2}$ Their desire for peace and good order could not have been more genuine.

But peace and good order could be understood in myriad ways. Time and again, despite intensive diplomacy and laborious participation in conferences, the process of peacemaking raised questions about the capacity of legal principles and treaty obligations to constrain what Leo Tolstoy called in the second epilogue of War and Peace "the movement of peoples" or "the power that moves peoples." From the perspective of Russian diplomacy, the movement of peoples in Spanish America, Spain, Naples, Portugal, and Piedmont threatened 
European peace and exposed fissures in the general alliance. In $182 \mathrm{I}-22$ the beginnings of the Greek independence movement and the Russian-Ottoman war scare further underscored the fragility of allied unity, as well as the potential for opposition in Russian society. From the time of the Greek uprisings through the first years of Nicholas I's reign, Russian monarchs and their allies repeatedly chose peace through compromise and the avoidance of confrontation. More than revolution, the peacemakers feared war, and in their experience, war could be prevented only by preserving the European alliance. For several decades, this shared assumption encouraged the concert of great powers to moderate military ambitions on the continent. At the same time, conditions on the ground, among the peoples and their movements, increasingly showed that the accepted framework for peace and order could not contain the larger global dynamics impinging on European realities and relationships. European order did not depend solely on developments in Europe, where it would take more than the actions and commitments of the great powers to preserve peace.

\section{Staging the Alliance in Laibach (I82I)}

When on 30 December I820/II January I82I the allies resumed deliberations in Laibach, they already had agreed to intervention in the Kingdom of the Two Sicilies. On 4 February, an Austrian army of 35,000 crossed the river Po into Italy. On 13 February, the government in Naples declared war, and King Ferdinand I's son, Francesco, pledged loyalty to the constitution. ${ }^{4}$ On 23 March, Austrian troops occupied Naples, and by summer it became clear that their presence would not lead to protracted military conflict. The Neapolitan revolutionaries failed to mount a united resistance, and no broad-based popular uprising in defense of the constitution occurred; consequently, the restoration of the king did not require severe or murderous measures. ${ }^{5}$ On 24 June I821, Austrian foreign minister Metternich could write to Russian co-minister of foreign affairs Nesselrode that the work of the three monarchs (Alexander I, Francis I, and Frederick William III) had produced real and positive results. Nor had the British and French governments raised additional objections to the allies' course of action. France remained a hotbed of revolution, but Metternich believed that for the moment Italy had been pacified. ${ }^{6}$

For the moment, indeed. As Russia's diplomats continued negotiations in Laibach, they paid close attention to how allied actions in Naples would be represented and received. They insisted that the intervention adhere to the legal forms and prescriptions of the Quadruple and general alliances. Equally significant, 
they did not equate the repression of constitutional government in the Kingdom of the Two Sicilies with outright rejection of liberal political principles. Even the influential foreign policy adviser Aleksandr S. Sturdza, who consistently defended the dignity of sovereigns and religion, feared that intervention might provoke war between Ferdinand I and his son, the heir presumptive. ${ }^{7}$ As Sturdza admitted in a report to co-minister of foreign affairs Kapodistrias from 31 December 1820/12 January I821, the germs of revolution had taken root in Germany, Italy, and Switzerland. Europe had divided into two systems, one old and the other new. Among the states constructed on ancient foundations (anciennes bases), Sturdza named the great powers-Austria, Prussia, and Russia-together with second-order powers such as Denmark, Electoral Hessen, Hanover, the Roman (papal) state, Sardinia, and Saxony. States built upon the new constitutional system included Baden, Bavaria, Britain, France, the Netherlands, Portugal, Spain, Sweden, the Two Sicilies, Württemberg, and the two peninsulas (sic) of the American continent. The European political system, in other words, had changed forever.

The constitutional party, in Sturdza's analysis, had become preponderant and therefore commanded resources such as the universal language and the universal motor composed of money, commerce, navigation, and science. Religion, by contrast, had become a weak weapon in the struggle against "the unbridled tendency toward general emancipation." Referencing the revolutionary situation in Spain, Sturdza pointed out that entire social classes had lost their property, the press refused to publish opinions favoring the legal regulation of speech, and sectarians of license (sectateurs de la license) now controlled the inquisition. In these conditions, defenders of the old system, struggling to counter exalted passions and revolutionary storms, possessed only one means of resistance: the austere voice of experience and duty, grounded in good faith and love of God. Sturdza saw in the pacification of Naples not a solution to, but a respite from, the revolutionary assault on religion and duty, which in its recent manifestations had gone beyond what even the French Jacobins had attempted. Sturdza's recognition of the revolutionary threat seemed at once prescient, reactionary, and potentially reformist. Alongside irreligion, he also cited injustice and fiscal insolvency as vulnerabilities that explained the rebels' success. But while intellectuals and diplomats such as Sturdza believed that only the wholesale defeat of revolution could guarantee peace, the so-called holy allies interpreted their right to intervene in Naples differently. ${ }^{8}$

The intervention in Naples was at once a suppression of revolution and a policy of enlightened reform. As the conferences in Laibach demonstrated, neither at home nor abroad did the Russian monarchy espouse unyielding opposition to 
political change. 'Although the holy allies, supported officially by France's representative and unofficially by Britain's, had refused to recognize the revolutionary government in Naples or negotiate with its representative, they nonetheless assumed that King Ferdinand I's restoration would include political reforms. ${ }^{10}$ At the start of the meetings, the Russian government once again pushed to conclude a legal act that all the governments of Europe might sanction. Characterizing the Troppau decisions as preparatory and preliminary, Russia's diplomats tried to enhance the solemnity and legality of the final decisions that would be made in Laibach. An official opinion approved by Emperor Alexander on 30 December 1820/II January I82I argued for a formal allied statement, based on the recognized legal principles that governed the meetings of the European sovereigns and their plenipotentiaries. According to the Russian government, in matters such as the revolution in Naples, allied deliberations constituted a legal duty unrelated to questions of convenience or suitability. Russia's position did not imply that a new political alliance should be formed; rather it aimed to affirm the system that had given peace to Europe, independence to nations, and the means for governments to promote the happiness of their peoples. In accordance with established treaties, which required allied action on behalf of governments threatened by the events in Naples, the Italian states also had been invited to Laibach. In the end, given Britain's continuing neutrality, the allies expressed appreciation for, but nonetheless rejected, the Russian proposal. As the plenipotentiaries of Austria, France, and Prussia put the matter, the forms followed in Troppau seemed adequate to ensure that the policy of unity and general solidarity would continue to define relations among European states. ${ }^{11}$

During January I82I, the three sovereigns who had accepted the Troppau protocol also reached agreement with King Ferdinand I of the Two Sicilies, who pledged to mediate between his people and the European alliance to eliminate the menace posed by the Neapolitan Revolution. Ferdinand had been allowed to leave Naples on the assumption that he would defend the constitution; however, upon arriving in Laibach, he reversed course and requested allied assistance to restore his authority. ${ }^{12}$ With the understanding that the great powers would take no action before all possible means of reconciliation had been attempted, the king accepted the allies' refusal to recognize the current subversive government, including its representative in Laibach. Ferdinand thus appointed his own plenipotentiary, the Duke of Gallo, whom he called to Laibach to hear the explanations of allied policy. ${ }^{13}$ The Duke of Gallo would return to Naples with a letter from Ferdinand to his son, the Duke of Calabria, denouncing the political changes implemented since 2 July 1820 . The Duke of Gallo also would deliver 
joint instructions to the diplomatic representatives of Austria, France, Prussia, and Russia who served at the court of Naples. Again, Britain remained neutral, as did the Roman state; however, the plenipotentiaries of the Italian states of Modena, Sardinia, and Tuscany all accepted the plan. ${ }^{14}$

On I8/30 January, the Duke of Gallo met with allied plenipotentiaries to hear the instructions and dispatches that he would deliver to Naples. ${ }^{15}$ As the conference pronouncements made clear, the allies expected the king to be restored to power, and they promised not to impose a war levy on the population of the Two Sicilies as long as formal resistance did not materialize. Tellingly, the allocution delivered by Metternich also implied that the great powers possessed the authority to decide what course of action served the true interests of the Two Sicilies and Europe. Peace and well-being, the allies consistently proclaimed, could be ensured only within the general alliance, which the current Neapolitan government had abandoned. ${ }^{16}$

Among the documents presented to the Duke of Gallo, a Russian rescript of 9/2I November I820 described the transactions of I8I 4 , I8I5, and I8I8 as a pact of solidarity among all the Christian states of Europe, which aimed to ensure the territorial integrity, political independence, and internal tranquility of each country. ${ }^{17}$ Addressed to Count Gustav O. Stackelberg, Alexander I's envoy in Naples, and composed before Ferdinand I of the Two Sicilies agreed to come to Laibach, the rescript included the invitation to the king. ${ }^{18}$ Stackelberg was instructed to act in concert with the representatives of Austria and Prussia to persuade Ferdinand that only by meeting with the allied sovereigns in Laibach would he be able to save his country from the disasters of revolution and war. Only by accepting the allied proposal could he lead the Two Sicilies to reconciliation with itself and the world. If the king asked why the British and French monarchs had not signed on to the invitation, the Russian envoy was told to reply that irrespective of the invitation, Britain would never legitimize the revolution in Naples and France would cooperate with the allies to ensure the repose of Europe. Indeed, in I8Is France had accepted allied guarantees (guaranties concertées) of its institutions, and in 1818 the country had been admitted into the general alliance. Allied policy toward the Two Sicilies followed exactly this course: the location had changed, but not the system (or policy). In I8I5 the powers had embraced the European cause, and in I820 they intended to defend it. ${ }^{19}$

The Russian version of the common instructions accepted in Laibach also was addressed to Count Stackelberg. ${ }^{20}$ The instructions began with a review of key points elucidated in earlier documents. Motivated by duty to their states and the 
world, the allied sovereigns had negotiated with Ferdinand I of the Two Sicilies, who intended to mediate between his people and the alliance, from which his kingdom had been separated since the July events. Committed to the path of reconciliation, the king hoped to save his country from further misfortunes, while the allies sought to save neighboring states from the threat posed by the revolution. The allies had decided to act during the conferences in Troppau, where they also had recognized that the Neapolitan Revolution could not be treated as an isolated event. Unfortunately, despite the ongoing benefits of the general pacification, the spirit of trouble and disorder, the cause of widespread desolation, had revived. The situation in the Kingdom of the Two Sicilies had become so grave that the current allied action, based on the transactions of $\mathrm{Vi}$ enna, Paris, and Aix-la-Chapelle, could only be interpreted as favorable to the general interest in the repose and happiness of all Europe.

The sectarians in Naples, by contrast, seeking political reform through revolt and crime, in reality had attacked religion, morality, and social bonds. Equally significant, they had violated their vows to a legitimate sovereign. Having usurped the king's authority, their revolution could lead only to anarchy and military despotism. The allies appreciated Ferdinand I's desire to avoid civil war through compromise; however, they would never accept the current government and so had taken steps to end the disorders, preferably by force of reason. Simply put, the allies expected the king to persuade his peoples to suppress the revolutionary regime, a course that spontaneously would return the Two Sicilies to amicable relations with the states of Europe and to membership in the general alliance. With this goal in mind, the allies had invited Ferdinand to explain how he planned to restore an order of things that could ensure the well-being, true interests, and stability of his subjects and the future security and tranquility of neighboring states. If this outcome could not be achieved, the allies would have no choice but to use armed force to end the disorders.

As the instructions to Stackelberg further recounted, King Ferdinand understood and accepted the allies' terms. To save his peoples from war and coercive measures, he wished to persuade them to disavow the political changes that had occurred. He believed, moreover, that his paternal voice would be heard. The monarch's message would be communicated in a letter to his son, the Duke of Calabria, describing the negotiations in Laibach. Stackelberg and other allied representatives on the ground in Naples would then be responsible for explaining to the duke that his father's letter also corresponded to the decisions of their respective sovereigns. In the process, they would exhort him to recognize the urgency of the situation, repudiate the revolution, and accept his father's advice. 
In two additional dispatches, both dated 19/3I January 1821, Stackelberg received further instructions concerning communications with the Duke of Calabria about allied policy, the cooperation of King Ferdinand I, and plans for a temporary army of occupation that might or might not be used. ${ }^{21}$ Again, the instructions repeated previous admonitions about the unacceptability of the current government, the isolation of the Two Sicilies from the states of Europe, the king's desire to serve as mediator in reconciling his country with the alliance, the need to guarantee peace and repose for all the governments of Italy, and finally, the inevitability of war, if the kingdom did not reject the revolutionary regime, which threatened the "happiness, strength, and survival of every political and civil society." ${ }^{\prime 2}$ Here too Stackelberg's task was to convince the duke that peace, prosperity, and the exercise of legitimate rights were incompatible with the existence of a government formed in revolt. For this reason, if military intervention became necessary to end the crisis and restore the king's authority, Emperor Alexander stood ready to send Russian troops to assist the allied army. Again it seems that although the great powers did not intend to compromise the territorial integrity or independence of Ferdinand's kingdom, they did presume to define the true interests of a second-order state.

After concluding negotiations with King Ferdinand and explanations with the Duke of Gallo, the allied plenipotentiaries discussed Austria's plan for the army of occupation. Presented by Prince Metternich, the Austrian proposals described the troops poised to cross the river Po and march into the Kingdom of the Two Sicilies as an allied army operating on the basis of the transactions of Troppau and Laibach. ${ }^{23}$ The army would assist Ferdinand in an auxiliary capacity, and assuming that voluntary submission to the king's authority occurred, no indemnity or military contribution would be imposed on his peoples. The Austrian plan also called for an occupation of three years, regulated according to the forms that had been followed in France after the victory over Napoleon. The allies then promised to help Ferdinand financially, primarily as loan guarantors, and to meet with him in 1822 to evaluate the kingdom's internal condition and the duration of the occupation. The conference journal for 2I January/2 February I82I recorded formal approval of Austria's military proposals, including Alexander's pledge to provide financial assistance to Ferdinand. Prussia’s plenipotentiary also responded positively, though he had not yet received instructions from his government about the financial guarantees. France likewise accepted that coercive measures might be necessary but refused to participate in a war against Naples; and the British representatives, who were not authorized to give an opinion, affirmed their king's commitment to the alliance. The 
representatives of Modena, the Roman state, Sardinia, and Tuscany likewise lacked the authority to discuss military intervention but deferred to the presumably wise views of the Austrian emperor. ${ }^{24}$

After reviewing Austria's plan for the occupation, the allies considered King Ferdinand's project for political reconstruction. ${ }^{25}$ At the conference of $8 / 20$ February I82I, Prince Ruffo, acting as royal plenipotentiary, presented the king's thoughts (pensées) on the principles of reform. ${ }^{26}$ To enhance the monarch's understanding of the needs and interests of his peoples, the plan envisioned separate administrations for Naples and Sicily, united under one scepter. In both parts of the kingdom, a consultative body would debate legislation and administrative measures prior to enactment, on the assumption that the "interests of the crown, the well-being of the kingdom, and enlightened justice" were of a piece. Provincial councils would allocate taxes, and communal administration would serve the needs of the communes and the preservation of their patrimony (patrimoine). Over the next two days, Austria, France, Prussia, Russia, and the participating Italian states (Modena, the Roman state, Sardinia, and Tuscany) approved the proposed principles of reform. In supporting Ferdinand's ideas, Emperor Alexander highlighted the favorable response of the Italian states, which were most impacted by the events of 2 July, and expressed the hope that application of the proposed principles would, in accordance with article 4 of the protocol of $7 / 19$ November 1820 , lead to the creation of a stable order of things. Ideally, this order of things would be built upon foundations that would not require foreign assistance to guarantee the tranquility and independence of the Italian states. ${ }^{27}$

The formal closure of the Laibach conferences took place on $14 / 26$ February I82I. Austrian troops had entered the Kingdom of the Two Sicilies on 6 February, and on 7 March the Neapolitan army would be destroyed at Rieti. Satisfied that the principal goal of the Troppau and Laibach meetings had been achieved, the allies agreed to reconvene in Florence in September 1822. ${ }^{28}$ The three sovereigns also arranged to stay in Laibach to monitor the intervention. ${ }^{29}$ It seemed as if the allies had succeeded in both addressing the revolutionary situation in Naples and preserving the alliance, despite disagreements. But they would enjoy only a brief respite from further crisis. On 9-10 March I821, insurrection broke out in the Kingdom of Sardinia-Piedmont, where yet another provisional government proclaimed the Spanish constitution of I8I2. King Victor Emmanuel I abdicated in favor of his brother, Charles Felix, who then fled to Laibach to appeal for allied support. Austria again intervened and on 8 April defeated the Piedmontese Revolution. ${ }^{30}$ To justify this unanticipated action, the 
plenipotentiaries of the three powers, still in Laibach, issued a declaration, dated $30 \mathrm{April} /$ I2 May I82I, which explained the need to repress rebellion in both Naples and Piedmont. ${ }^{31}$ Their swift response did not, however, end the revolutionary threat. Greek subjects of the Ottoman Empire, a special Russian interest, also rebelled in March, and within a few months the allies faced the prospect of renewed war. In the midst of the volatile Greek crisis, Emperor Alexander I again worked to preserve allied unity and organize concerted action, based on the agreements of 1814,1815 , and 1818 .

\section{The Russian-Ottoman War Scare of I82I-22}

Allied decisions in Troppau and Laibach assumed that not only military success but also public perception of the intervention in Naples had broad implications for peace in Europe. The Spanish Revolution continued to be a problem, though before the allies could collectively address that situation, the start of the Greek independence movement created a more immediate crisis. Following the outbreak of the Greek insurrections, the future of the Ottoman Empire, the so-called Eastern Question, emerged as a critical problem for European diplomacy. During the crisis of I82I-22, Russia's diplomats focused on the same issues of rebellion, intervention, and legitimate sovereignty that had occupied the alliance since the revolt in Spain. In the Ottoman sphere, however, the potential consequences of intervention extended beyond the suppression of insurgency into the centuries-old relationship between Christianity and Islam. Russia in particular had a long history of military conflict, political entanglement, and treaty relationships with the Ottoman Empire. From the perspective of Emperor Alexander I, the legal obligations already binding the two empires appeared no less essential to European order than the transactions of 1814 , I8I5, and I8I8. Further complicating the situation, Russian-Ottoman tensions carried broad implications for the interests of other great powers operating in the Balkans, the Mediterranean, and North Africa. Precisely because the allies continued to believe in allied unity and to view European society as a distinct entity, their most immediate goal became the avoidance of war and preservation of the Ottoman Empire. To achieve this goal, they needed to monitor one another's thoughts, actions, and intentions, which they tried to do through the substance and staging of concerted action.

The backdrop to the crisis of I82I-22 lay in the Russian Empire's military and diplomatic successes during the late eighteenth and early nineteenth centuries. Following the military conflicts of $1768-74$, I787-92, and I806-I2, Russia 
occupied a strong position in the ongoing struggle with the Ottoman and Persian empires to control the Balkans, the Caucasus, and Transcaucasia. Critical Russian interests included internationalization of the Black Sea, free commercial navigation through the Straits of the Bosporus and Dardanelles, protection of the Christian religion and Orthodox coreligionists living under Ottoman rule, support of Balkan aspirations for political autonomy within the framework of Ottoman suzerainty, and finally, in the aftermath of the Napoleonic Wars, use of the European political system to preserve peace and ensure adherence to established treaty obligations. With the Treaty of Bucharest, signed in $18 \mathrm{r} 2$, the Russian monarchy committed itself to preservation of the Ottoman Empire, enforcement of recognized territorial agreements, the principle of legitimism, and defense of sovereign authority. ${ }^{32}$ Still, the reconciliation proved fleeting, for even in the best of times, the potential for conflict between these chronic foes only partially abated.

In the era of European restoration, implementation of the Porte's treaty obligations to Russia did not proceed as Emperor Alexander I had hoped. Tensions quickly arose over delimitation of the Caucasian border, Russia's role as defender of Serbia's recently acquired political autonomy, and guarantees of free navigation in the Black Sea and the straits. ${ }^{33}$ Negotiations conducted by Alexander's envoy Baron Grigorii A. Stroganov were ongoing, and as late as June I817, the Russian government continued to proclaim that the Porte sought friendship and that the diplomatic endeavors in Constantinople would produce results. Russian-Ottoman disputes also had been addressed during the Congress of Vienna, though the Hundred Days had ended the discussions, and going forward Alexander rejected the possibility of European participation in this long-standing bilateral relationship. In the monarch's view, neither the Ottoman nor the Persian Empire belonged to the political association defined by the treaties of Vienna and Paris. ${ }^{34}$ This approach prevailed until March 1821, when rebellions erupted among the Ottomans' Greek subjects. Within a few months, the threat of yet another Russian-Ottoman war loomed large. ${ }^{35}$

The immediate crisis in $182 \mathrm{I}$ resulted from multiple uprisings among the Christian subjects of the Ottoman Empire: Greeks in Moldavia, led by Alexandros Ypsilantis (Alexander Ypsilanti), who recently had retired from Russian military service; Greeks in the Morea, in Attica, Thessaly, Macedonia, Epirus, and the Aegean Archipelago; and a peasant revolt in Wallachia, led by Tudor Vladimirescu against the Ottoman-appointed hospodar (governor) and great landowners. Equally ominous, Turkish reprisals against Christian civilians in the Danubian Principalities and Constantinople led to the destruction of 
churches and the murder on Easter eve (22 April 182I) of Ecumenical Patriarch Grigorios V. ${ }^{36}$ Although Baron Stroganov continued to report diplomatic progress, these developments, together with ongoing violations of Russia's economic and other treaty rights, convinced Emperor Alexander that the Porte intended to wage war against the Orthodox religion. ${ }^{37}$

Torn between the obligation to protect Christian subjects of the Ottoman Empire and the post-Napoleonic commitment to legitimist principles, Emperor Alexander consistently opposed the Greek rebellions. By late June, the revolts in the principalities had been suppressed. ${ }^{38}$ But Ottoman troops remained, and atrocities, committed by Greeks and Turks, continued. ${ }^{39}$ In these circumstances, diplomatic declarations had no effect, and on 6/18 July i821, Baron Stroganov delivered an ultimatum addressed to the Porte by the Russian government. Russia's demands included: (I) restoration of destroyed and damaged churches; (2) protection of the Christian religion and the rights of Christians; (3) recognition of the distinction between innocent Greeks and those responsible for the troubles; and (4) a role for Russia in the pacification of Moldavia and Wallachia, as established by the spirit of existing treaties. Stroganov's instructions also authorized him to soften the tone of the note, if he thought such a gesture might be useful or justified. But the Porte remained silent, and once the specified eight-day waiting period had passed, the Russian envoy carried out his orders to leave Constantinople with all diplomatic personnel. After this formal break in diplomatic relations, the possibility of war became very real, encouraged in Russia by key foreign policy and military advisers and by pro-Greek sympathies in educated society. A period of dangerous uncertainty and grinding diplomacy ensued. Eventually, the Russian monarch, who had condemned the Greek rebels from the outset, opted for peace in the interest of European unity. ${ }^{40}$ How did this happen, and what did it reveal about Russia's relationship to Europe?

When news of the Ypsilantis revolt reached the allies in Laibach, Emperor Alexander immediately disavowed support for both Ypsilantis and Greek rebellion against Ottoman authority. At the same time, the Russian monarch expected a collective response from the allies and therefore wanted to ascertain what their position would be if circumstances forced him to take military action (as Austria had done in Italy). More modestly, he hoped that the allied governments would publish a common declaration on the crisis, in order to mold public opinion and limit unfavorable press coverage. Beginning in the spring of $\mathrm{I} 82 \mathrm{I}$ and continuing into October, Russia's diplomats in Berlin, London, Paris, and Vienna received instructions to pressure allied courts to support Alexander's call for concerted action. The monarch also communicated directly with Francis I, George IV, and 
British foreign secretary Castlereagh. ${ }^{41}$ Britain already had opposed intervention in Naples, but Russia still hoped to win Austrian, British, and French support in case of war with the Ottoman Empire. ${ }^{42}$

In $1821-22$, even though the Ottoman Empire did not belong to European society, Russia's policymakers approached relations with the Porte and insurrection in Moldavia, Wallachia, and Greece from the perspective of the European system. They assumed, therefore, that the maintenance of peace could not be left to any one great power. Because the European alliance had a role to play and a responsibility to fulfill, Russian diplomats, including the tsar diplomat, insisted that both the European allies and the Porte adhere to established treaty obligations and that the Ottoman Empire resume its place in the (European) political order. Thus, when the Russian government informed the allies of the July ultimatum to the Porte, Emperor Alexander also appealed for support and suggested that collective military force might be needed to pacify the East. ${ }^{43}$ Convoluted as this thinking sometimes appeared, it had the effect of prioritizing allied unity in the pursuit of international reconciliation.

The note of 6/18 July, delivered to the Porte by Baron Stroganov, began by proclaiming Russia's commitment to the conservation of the Turkish government, considered necessary for the maintenance and consolidation of peace in Europe. ${ }^{44}$ After the first signs of insurrection had appeared in Moldavia and Wallachia, the Russian government had encouraged the Divan, the supreme council of the Ottoman government, to take measures to suppress the revolutionary evil. Equally telling, over the previous five years, Russia's diplomats had worked to ensure the "religious fulfilment of the treaties." In other words, through cooperation with the Porte, Russia sought to stamp out rebellion and end the calamities afflicting the people of the principalities, who, despite the insurrection, nonetheless remained innocent and loyal to the Ottoman government. Russia accepted the need to use military force to deliver Moldavia and Wallachia from the foreigners who had undermined internal tranquility; however, such force should be deployed wisely under the protection of a reparative government and in accordance with the public law of the principalities. Unfortunately, rather than following this course, Ottoman policy encouraged sympathy for the very people who attacked the Porte's authority. In this manner, the Porte imparted to insurrection the character of a legitimate defense of the Greek nation and its church. ${ }^{45}$

During past crises, the Russian note continued, the Ottoman government had not encouraged Muslim subjects to persecute Christians. In this instance, however, the conditions of coexistence that for so long had prevailed in the 
Porte's European territories had been violated. Four centuries had passed since such vicious attacks on Christianity, exemplified by the murder of the patriarch and the destruction of churches, had been witnessed. The Porte, in other words, appeared to be waging war against the Christian religion. Unable, therefore, to find in the existence of the Ottoman Empire a guarantee of peace, Russia faced the prospect of being forced to defend its "insulted faith, broken treaties, and persecuted coreligionists." At this juncture, the Porte should recognize, based on the representations of the great powers, that Russia's cause constituted a European cause. The Christian monarchs of Europe would not be able to ignore the repressions inflicted both on the people responsible for the troubles and on the Greek nation en masse. Current Ottoman policies clearly threatened European peace, offended the Christian religion, and amounted to the extermination of a Christian people.

Although Russia's immediate actions purportedly aimed only to defend the general interest, the treaties of Kuchuk Kainardji (I774) and Bucharest (I8I2) also remained in effect. Kuchuk Kainardji stipulated Russia's right to protect the Greek religion in all the states of the Ottoman Empire. Bucharest assigned to the Russian government political rights in Moldavia and Wallachia. Thus, in pressing Russia's claims against the Porte, the note of 6/18 July i821 subsumed under the mantle of the European alliance the right to protect the Christian religion and Christian subjects of the Ottoman Empire, as prescribed by earlier treaties. Invariably proclaiming the pure and peaceful intentions of the Russian monarch, the language of the note ignored potential distinctions between the Greek church and other Christian denominations, as well as between Greeks, Moldavians, and Wallachians, whose insurrections unfolded as separate movements. ${ }^{46}$

Baron Stroganov's ultimatum to the Porte likewise insisted that Russia's demands remained what they always had been. Furthermore, because the Porte's policies posed a danger to the Ottoman Empire itself, acceptance of the conditions would bring salvation to the Turks. Either the Porte had been operating under the influence of fanatics or its policies had resulted from free will and a well-reasoned plan. In either case, Emperor Alexander demanded an explanation, while also expressing the hope that the current policy could be altered by removing from power a few lost men. By accepting Russia's claims, the Porte would show that it possessed the power to change course and once again engage in negotiations with Christian governments. Pacification in the principalities of Moldavia and Wallachia, to which Russia should contribute based on the spirit of the treaties, could then become a model for the pacification of Greece. If, by contrast, the Porte did not end the repressive and inhuman measures now being 
applied, the Ottoman Empire would be in a state of open hostility against the Christian world. Russia's government would have no choice but to offer refuge to Greek combatants, whose struggle would be legitimized. In other words, instead of cooperating with the Porte to end the uprisings and restore tranquility to the insurgent provinces, Russia and the Christian world would be duty bound to protect their brothers in religion from blind fanaticism. Russia remained committed to the conservation of the Ottoman Empire and the fulfillment of established treaty obligations. It was the Porte's responsibility, however, to take steps to end the troubles. ${ }^{47}$ As Russian diplomats depicted the situation, the Porte refused to accept the very conditions that would ensure its own salvation. Consequently, the break in diplomatic relations had become unavoidable, and the threat of military conflict had intensified.

Because the departure of an entire diplomatic mission usually represented a step toward war, the rift between Constantinople and Saint Petersburg forced the allies to focus on Emperor Alexander's conditions for the restoration of Russian-Ottoman relations. Among the communications generated by the diplomatic crisis, historians have paid particular attention to Britain's role as allied negotiator. In reality, the Russian government did not view allied diplomats as negotiators or mediators. Their accepted role was to pressure the Porte to meet the monarch's legal demands, and in the event of failure, to establish a "concert of views and principles between Russia and the allied powers. ${ }^{348}$ Even before the formal break in relations, Russia's diplomats had connected the crisis in the East to European order and the general alliance. In a letter of 22 June/4 July I82I, Kapodistrias had explained to Baron Pavel A. Nikolai, Russian chargé d'affaires in London, that the Porte's actions could only be interpreted as hostile toward Russia. ${ }^{49}$ Kapodistrias blamed the British ambassador in Constantinople, Lord Strangford, for the allies' failure to respond to Russian appeals and insisted that they support Baron Stroganov's negotiations..$^{50}$ The issues identified by Kapodistrias included Russia's demand that the Porte fulfill established treaty obligations and respect the Christian religion. Equally significant, Kapodistrias reiterated that Emperor Alexander had never supported the Greek insurrections and had even tolerated Ottoman reprisals against rebellious subjects.

From the summer of $182 \mathrm{I}$ until the war scare temporarily abated in the spring of 1822 , the Austrian and British governments remained suspicious of Emperor Alexander's objectives and worked collaboratively to prevent a Russian-Ottoman war. Although the issues they identified and the diplomatic arguments they presented did not necessarily correspond, for Russia, the potential dangers of Austrian-British cooperation became painfully evident when Metternich and 
Castlereagh met in Hanover from 20 to 29 October I82I (NS). During the years of arduous diplomacy that followed the Congress of Vienna, the appearance of a unified alliance could be as important as substantive agreement or disagreement. Thus, under the guise of unity, Christoph Lieven, Russia's ambassador in London, traveled to Hanover to convey Emperor Alexander's confidence in his allies. ${ }^{51}$

Lieven arrived in Hanover on 28 October, having learned along the way that Count Bernstorff, Prussia's minister of foreign affairs, had been invited to the meetings, but had declined to attend. ${ }^{52}$ Based on conversations with Castlereagh, Lieven then reported to Nesselrode that because the allies feared military conflict, they had not responded to Russia's efforts to ascertain what their positions would be in case of war. Metternich and Castlereagh agreed, however, to instruct their respective diplomats in Constantinople to pressure the Porte to compromise, so that direct communications between the Russian and Ottoman governments could be restored. The ministers seemed to understand that before negotiations could resume, Russia expected to see evidence of military evacuation and just administration in the Danubian Principalities. Both ministers also wrote to Alexander not only to offer moral support, but also to express opposition to military action. For the moment, Britain opposed both Greek independence and the removal of Ottoman power from Europe. Although Lieven generally presented British policy in a positive light, he nonetheless saw in the Hanover meetings the potential for "a separate alliance [combinaison isolée], alien to the interests of Russia and contrary to the principles of the general alliance. ${ }^{53}$ Russia's envoy in Vienna, Iurii A. Golovkin, stated outright that with respect to the Eastern Question (la question orientale), Austrian and British interests stood in opposition to those of Russia. ${ }^{54}$

In Castlereagh's conversations with Lieven (as reported by Lieven), the British foreign secretary highlighted three issues: apprehensions based on Russia's diplomatic communications, particularly the ultimatum to the Porte of 6/18 July I82I; the British government's refusal to consider participation in an armed conflict; and finally, fears about the consequences of a war, including the political alliances that might result. Lieven believed that he had effectively calmed British anxiety about Russia's intentions, and as a result, Britain now accepted the Austrian version of Emperor Alexander's conditions for the restoration of Russian-Ottoman relations. In addition, although both Austria and Britain recognized Russia's demands as legal, just, moderate, and wise, the British government still hoped that Alexander would allow some leeway in the mode and form of Ottoman compliance. Lieven continued to claim that the British government misunderstood 
Russian policy, and while in Hanover, he insisted that Alexander's demands could not be altered. Not only did they represent the only way to prevent war; the monarch also had a right to ask his allies to insist that the Porte comply. This did not mean that the desire for allied support and agreement in case of war constituted a call for military action. Emperor Alexander aimed only to preserve peace by means of an allied entente. In other words, it was critical that the enemies of disorder not be able to view Russian-Ottoman hostilities as an isolated war that portended the dissolution or weakening of the European alliance. ${ }^{55}$

Despite Lieven's concerns about a four-power entente (Austria, Britain, France, and Prussia), he did not equate the Hanover meetings with the formation of an allied grouping directed against Russia. ${ }^{56}$ To the contrary, Austria and Britain, while eager to prevent war, did not want to offend Alexander. Suspicions among the allies threatened their unity, but in the present circumstances, even if Russia went to war, Lieven did not expect the alliance to be harmed. In fact, he anticipated allied support for Russia, if military conflict erupted. With hindsight, Lieven's appraisal seems overly optimistic. The ambassador assumed that Britain recognized Russia's treaty right to protect the Greek population of the Ottoman Empire, and he characterized Alexander's immediate goal as effective pacification of the Danubian Principalities. The monarch's conservative policy treated the principalities and Greek territories as Ottoman provinces. Equally promising, Russia's position accorded well with Castlereagh's reported belief that European peace would be better served if Christians lived within the Ottoman Empire. This would ensure the presence of a Christian population, as opposed to millions of "fanatical" and "vengeful" Muslims, along Russia's borders. What Lieven did not mention, or perhaps did not understand, was that Alexander's policy of pacification assumed a role for Russia inside the European provinces of the Ottoman Empire, including the archipelago and mainland of Greece. As Nesselrode explained in a confidential expedition to the ambassador, dated 27 November/9 December 1821, Russia had to be associated with any peace proposals directed at the Greeks, based on the empire's treaty right to protect coreligionists. ${ }^{57}$ But before this could happen, Russia's diplomatic relations with the Ottoman Empire had to be restored. In other words, pacification of the Porte's rebellious subjects could not begin before Lord Strangford convinced the Ottoman government to implement Russia's requirements for the renewal of diplomatic negotiations.

At the end of December 1821, Austria, Britain, and Russia had not yet found a common path forward that could prevent war between the Russian and Ottoman empires. In a personal letter from Kapodistrias to Lieven, dated 27 November/9 
December I82I and approved by Alexander I, the co-minister of foreign affairs emphatically proclaimed that neither the Austrian nor the British government understood Russia's position vis-à-vis the Porte. ${ }^{58}$ Rather, both seemed to interpret the monarch's diplomatic maneuvers as an effort to legitimize war, while drawing the allies into support for Russia-an interpretation that (from the Russian point of view) months of diplomacy contradicted. The focus of Kapodistrias's letter concerned Russia's obligation to protect the Christian subjects of the Ottoman Empire. Before Russia could negotiate, based on established treaties, the Porte needed to take concrete steps to fulfill Alexander's conditions, an intention that could be demonstrated only by implementing "principles of humanity and justice toward the Christians." Instead, the Porte had pursued a policy of vengeance and destruction directed against Greeks in Moldavia, Wallachia, Smyrna, Cyprus, and Crete. It was precisely Turkish persecution of Christians that had caused the rupture in Russian-Ottoman relations. Consequently, Emperor Alexander demanded a return to the conditions of March I82I, including respect for treaty obligations toward Russia's coreligionists.

A second issue identified in Kapodistrias's letter concerned the possibility that together the allies and the Porte might reach an agreement with the Greeks without Russian participation. The co-minister insisted that only through direct and active Russian involvement in the pacification of the principalities would it be possible to rectify the errors and moderate the hopes of the Greeks. But until Russia and the Porte returned to normal diplomatic relations, there could be no Russian participation. For seven months Alexander had asked only that the Ottoman Empire fulfill established treaty obligations. If the monarch had wished to drag the allies into war, he could have marched an army toward the principalities. The allies, having previously recognized the justice of Russia's grievances, would not have been able to condemn the military action. Assuming, Kapodistrias added, that Ottoman troops would have succumbed to Russian forces, Alexander also would have been in a position to dictate the terms of the peace. Yet in contrast to this scenario, the monarch's intentions remained moderate. Throughout the crisis he had kept in view the interests of the European system. For precisely this reason, he sought to engage the allies in a discussion of how, by acting in concert, they could preserve "the tranquility of Europe and the moral character of the European alliance." Once again, Kapodistrias instructed Lieven to try to convince the British government that the Russian monarch continued to seek peace, as he had done since the troubles began in Moldavia and Wallachia. At the same time, notwithstanding Alexander's patience, the monarch still considered war a possibility and hoped to obtain from the allies a commitment 
to address in concert any consequences that might result. Indeed, in the case of war, Alexander's calculations would concern not the exclusive interests of Russia, but those of the general alliance.

Lieven's conversations with Castlereagh, which had begun in Hanover, continued in London, where once again the ambassador failed to obtain a commitment to support Russia in a war against the Porte. ${ }^{59}$ Castlereagh did confirm, however, that Britain had no plans to mediate between the rebellious Greeks and the Ottoman government, a possibility suggested by the British role in negotiations between Spain and the Spanish American colonies. British mediation would require simultaneous invitations from both parties to the conflict, an unlikely development given the sensitivities of the Divan and the lack of local authority among the Greeks. Britain, committed to the survival of the Ottoman Empire, also rejected the idea of an allied guarantee that the Porte would fulfill its obligations to the Greeks. Nor did the British government believe that a general pacification of the Ottoman provinces would succeed or even be consistent with British interests.

Ambassador Lieven accepted that given the uncertainty surrounding the Greek crisis, the British government hesitated to pronounce on a course of action. Even after reports of Greek military success against Ottoman troops and greater unity among rebel leaders reached London, British leaders sought to preserve the Ottoman Empire, though they also expressed little confidence in the Porte's ability to restore order among its Christian subjects. Indeed, Castlereagh associated the Greek insurrections with revolutions in other countries and stated plainly that the Greek cause should not be characterized as a natural defense. The foreign secretary therefore hoped that Emperor Alexander would be able "to draw a line between the legitimate interest that the oppressed Greeks have the right to demand from Russia, based on the treaties, and the guilty men who march today under the banner of revolt." ${ }^{\text {60 }}$

Serious differences among the allies persisted, but by January 1822 , the great powers achieved a measure of consensus on how to approach the Greek question. They agreed that the Porte stood in legal violation of established treaties in relation to both Russia and the Greek/Christian population of the Ottoman Empire. The allies likewise viewed the Greek insurrections as part of the larger revolutionary upheaval spreading across Europe. Agreement on these principles did not, however, satisfy Alexander I's expectations or ease allied pressure on the monarch to soften Russia’s demands. In reports from December I82I and January I822, Russia’s envoy in Vienna, Iurii Golovkin, reported to Nesselrode that Metternich's depiction of the Eastern crisis aimed to make Russia appear responsible 
if war broke out. ${ }^{61}$ The Austrian government believed that a Russian-Ottoman war would represent the triumph of the revolutionary faction in Europe and therefore insisted that Russia drop the three moral demands contained in the ultimatum to the Porte. By contrast, the one legitimate material demand, evacuation of the principalities, should be preserved. Although Metternich viewed the Greek rebellions within the broader framework of stopping the spread of revolution in Europe - a goal that required allied agreement-Golovkin admitted that he had been unable to persuade the Austrian minister of the rightness of Russia's position. Golovkin also remained suspicious of Metternich's intentions, suspected a bilateral Austrian-British effort to intervene in the Greek cause, and expected Austrian neutrality in case of war. Equally concerning, Metternich continued to criticize Russia's acceptance of Greek refugees and to accuse Alexander's government of supporting Greek Etairists, members of a political organization originally based in Odessa who stood behind the Ypsilantis uprising and sought to liberate Greece through armed insurrection. ${ }^{62}$

Emperor Alexander's response to the Austrian claim that a war between the Russian and Ottoman empires would represent the victory of the revolutionary party in Europe appeared in a communication from Nesselrode to Golovkin, dated 31 January/I2 February 1822 and approved by the monarch. ${ }^{63}$ Nesselrode began by highlighting the shared commitment of the Austrian and Russian courts to preserving the moral force of the European alliance, the intimate union of the allied powers, and the European peace that the powers had enjoyed for the past seven years. In the mind of Alexander, the moral force of the alliance included protection of the peoples from subversive projects. Thus, the Russian government wanted to discuss whether or not war, which seemed inevitable, would advantage the revolutionaries, threaten the alliance, and imperil European peace. According to Nesselrode, the Russian answer to this question implied a need for action, whereas Austria's policy remained one of inaction. As Russia's diplomats repeated over and over again, since June i82I Emperor Alexander had sought an allied remedy to the crisis based on persuasion. But if the Porte continued the current course, the use of force would be necessary. Consequently, in the event of war, the Russian government stood ready to act in concert with the allies.

If agreed upon in advance, the Russian government believed, war would endanger neither the general alliance nor peace in Christian Europe. Russia had no desire to become the sole arbiter of the Ottoman Empire's destiny, and for this reason, the august friends of Emperor Alexander did not fear his intentions. Nesselrode tried to distinguish between Alexander's fellow monarchs and the 
allied governments fearful of Russia's aims. Critics of Alexander's foreign policy argued that a war against the Turks would make Russia an effective auxiliary of insurrection. They also expressed concern about the potential for Russia to become bogged down militarily, which could prevent the empire from assisting allies faced with revolution. Such fears were unfounded, Nesselrode insisted, for Russia had never supported the Greek rebels and had been prepared to offer military assistance during the troubles in Italy. Equally important, Emperor Alexander's principles in relation to Greece had always been noble and pure.

Nesselrode went on to identify two problems in need of an allied response. First, the allies must bring to an end the conflict between the Muslims and the Greeks; and second, they must address the obstinance of the Turkish government and the germs of anarchy and dissolution that existed within the Ottoman Empire. Since June, Nesselrode continued, Emperor Alexander had been asking his allies to deliberate on what their common response would be if the current crisis did not subside. Over the course of nine months the allied policy of conciliation had failed to mitigate the evil that ravaged the East. Although the crisis had originated in the Greek insurrections, the Porte's policy had aimed not to suppress the revolutionaries, but to attack the entire Greek nation. From the perspective of the Russian government, the Porte had pursued a war of extermination against Greek merchants, proprietors, and clergy, not just against sectarians. In other words, Muslims had been armed against Greeks in the name of religion. So if the allies hoped to dissuade the entire Greek nation from following the agitators, the Porte had to distinguish the innocent from the culpable. If the Porte hoped to achieve Greek submission to Ottoman authority, the innocent would have to receive guarantees of security, including pardons for those who had supported the revolutionaries in error.

But guarantees for the innocent would be useless, if the Ottomans continued to violate broader treaty obligations to Russia. If this happened, the present misfortunes would go on indefinitely, leading to the total annihilation of the Greek nation. To prevent this, either the Turks had to be persuaded to change course or armed intervention had to be used. Action in the Levant (the islands and coastal areas of the eastern Mediterranean ruled by the Ottomans) might produce unforeseen consequences; however, if the Porte did not cede to the power of reason, they would succumb to force. Russia would make clear that Emperor Alexander wanted to preserve the Ottoman Empire and the peace by cooperating with the Porte "for the reestablishment of tranquility in Greece on solid and durable foundations." This policy would not encourage illegitimate hopes, but by enhancing the Greeks' sense of security, it would allow them to repel agitators 
and choose a moderate path forward. Inaction, by contrast, would allow the troubles to continue, thereby increasing the revolutionary threat across Europe. In these conditions, Russia would not be responsible for the effects of inaction or the broadening crisis.

\section{Russia Chooses Peace}

Although recent scholarship focuses on Austrian-British efforts to block Russian action during the crisis of $182 \mathrm{I}-22$, there can be no question but that Emperor Alexander I sought to avoid war. Clearly, the monarch continued to see the European alliance as the best means to preserve peace. This is why historians of the Greek independence movement are careful to distinguish the rebels' expectations of Russian support from the actual assistance they did or did not receive.$^{64}$ Dmitrii P. Tatishchev's I 822 missions to the Austrian court-missions that Alexander hoped would persuade the allies to act in concert (concerter) to protect Russia's treaty rights-embodied the commitment to allied unity. The impetus to send Tatishchev to Vienna was Emperor Alexander's ongoing disappointment with efforts to dispel what he considered the Porte's illusions. None of the allies, especially Austria and Britain, had committed to strong support of Russian interests. After close to a year of diplomatic conversation and evasion, Austria had failed to press upon the Porte the legitimacy of Russia's demands. Instead, the threat of war had increased. To rectify this situation, Tatishchev received orders to convince Metternich of the need for (and justice of) forceful concerted action and, once again, to assess what Austria's reaction would be, if the Russian monarch decided to go to war. ${ }^{65}$

Emperor Alexander's instructions to Tatishchev appeared in a rescript dated 5/17 February 1822. ${ }^{66}$ From the outset the monarch made clear that Tatishchev's mission concerned the most vital interests-interests that the crisis in the East threatened and that could be protected only through the general alliance, as opposed to the exclusive combinations of the old policy. ${ }^{67}$ The substantive instructions began with a summary of Alexander's response to Austria's proposals of 23 December I82I concerning Russia's claims against the Porte, which was also transmitted to his agents at allied courts. ${ }^{68}$ By the time of the mission, Austria had assumed the lead role in allied negotiations with Constantinople, and as the Russian monarch made clear, at the Vienna court Tatishchev spoke for his sovereign. As the instructions emphasized, even though Austria represented the most likely allied participant in the crisis, Alexander expected cooperation from all the great powers. Repeatedly, he insisted that the grave matters at hand needed 
to be resolved collectively "in the spirit of the alliance and for the common salvation [salut] of all the States of Europe." According to the monarch, the current task of the European allies was to protect interests threatened by the crisis in the Levant, if necessary by deploying an armed force that would act for the general good in the name of the alliance. ${ }^{69}$ The interests at stake represented one aspect of Russia's relations with the Porte, and to compromise those interests would threaten the order of things enshrined in established treaties.

Having identified Russia's interests with the common European good and desire for peace, Emperor Alexander highlighted the danger posed by allied inaction and by failure to convince the Porte to change course so that diplomatic relations with Russia could be restored. Continuation of the impasse would force Russia to act alone, a step the allies clearly hoped to forestall. As if to counter allied apprehensions that he aimed to expand Russia's economic and territorial interests at Ottoman expense, Alexander warned that in the event of unilateral Russian action, the factions working to disrupt social order in Europe might easily conclude that the alliance was broken. ${ }^{70}$ The monarch reiterated his desire to avoid war, a position he believed Russian diplomacy already had established. However, if the Porte remained obstinate and the use of force became necessary, collective allied action would be more effective than any unilateral measures taken by Russia. Alexander rejected the potential claim that to address the Porte in the name of Europe was tantamount to recognizing the Ottoman Empire as a European power. To the contrary, the purpose of collective European action would be to return the Ottoman Empire to the position it had occupied in the political order of March 1821, before the start of the Greek rebellions.

Emperor Alexander's instructions to Tatishchev can be read as a justification of Russian demands and a plea for allied support. Repeatedly the monarch described the policy of the Ottoman government as a threat to the tranquility of Europe. Russia's calls for a formal allied guarantee to specify the actions that would be taken if the Porte refused to accede to Russian demands remained unanswered, though eventually the allies did promise moral support in the event of war. In the meantime, it was the job of Alexander's diplomats to prod the allies into articulating a unified position. Based on the events of the previous nine months, the monarch had concluded that without a change in the allied approach, the Ottomans would continue to violate established treaty obligations. Indeed, if the Porte rejected the modified conditions put forward by Austria, Russia expected to employ coercive measures in the name of the alliance. Alexander understood that any movement of Russian troops into the Danubian Principalities would lead to war, even if Russia did not declare war. But backed 
by an allied guarantee, the nature of which was not specified, this war of concert (guerre concertée) would quickly produce satisfactory results and would not compromise peace in other parts of Europe. Again, allied agreement in outlook and principle represented the best protection against the misfortunes caused by particular combinations-just the sort of combinations that Napoleon had used to break up multiple coalitions in the wake of French military victories.

Alexander ended the instructions by comparing the act he currently hoped to conclude with the Troppau protocol signed by Austria, Prussia, and Russia in November 1820. Russia's expectations of the allies followed directly from the actions negotiated in Troppau and Laibach. Never mind that Britain and France had not formally acceded to the Austrian intervention in Naples. They had not openly opposed it, and the rift had neither violated nor undermined the alliance. Similarly, if Russia acted alone to protect its interests in the East, this would not indicate a lesser commitment to the spirit of the alliance or to the principles upon which it rested. Ongoing communication, nimble and adaptable application of eternal principles to practical realities, mutual respect for the vital interests of the great powers, and an understanding of allied unity that allowed for unilateral military action — these were the hallmarks of the post-Napoleonic grand alliance.

Key to Emperor Alexander's eventual decision to opt for peace was the allies' recognition that Russia possessed a legal right to act. By February 1822, the time of Tatishchev's first mission, Russia had modified its original ultimatum to the Porte, based on the Austrian proposals supported by Britain. ${ }^{71}$ Henceforth allied communications concerning the conditions for renewed diplomatic relations employed Metternich's iteration of Russia’s demands: (I) restoration of destroyed Orthodox churches; (2) protection of the Orthodox religion; (3) recognition of the distinction between guilty and innocent Greeks; and (4) evacuation of the Danubian Principalities, accompanied by the appointment of hospodars and the establishment of a reparative administration. ${ }^{72}$ About a month after arriving in Vienna, Tatishchev could report to Nesselrode (10/22 March) that because the Porte still refused to evacuate the principalities and even demanded the return of territories ceded to Russia by the Treaty of Bucharest, Emperor Francis I now described the Porte's conduct as intolerable and expressed the belief that his fellow sovereign Alexander possessed the right to decide how Russia would obtain satisfaction. On $28 \mathrm{March} / 9$ April, Tatishchev again wrote from Vienna that the Austrian government continued to act in a spirit of justice and would accept the Russian monarch's decision about the use of force. Prussia also promised to adhere to allied diplomatic measures (2/14 March), and France acknowledged 
Russia's rights once the position of the other allies became clear. In early to mid-April, Russian officials still expected war, but they also remained confident that should hostilities become unavoidable, allied support-no mention was made of material support-would be forthcoming. ${ }^{73}$

This appraisal continued into May, when Ambassador Lieven regretfully reported that he had failed to obtain from officials in London the guarantee of support desired by his sovereign. The memorandum of 6/18 February, sent to Alexander I's representatives at the courts of Vienna, London, Paris, and Berlin, had included a proposal for a secret protocol whereby the allies would pledge to break diplomatic relations with the Porte (commercial agents could continue to operate) should the Porte not accept Russia's modified conditions. ${ }^{74}$ In keeping with Alexander's demand for proof of action on the fourth condition, the proposal called for complete evacuation of Moldavia and Wallachia, the establishment of a provisional administration under Greek kaimakams (until permanent hospodars could be appointed), and the appointment of Russian and Ottoman plenipotentiaries to regulate jointly the fulfilment of treaty obligations in the principalities. Because recognized treaties placed the Ottoman Empire's Christian provinces under Alexander's protection, the proposal assumed that Russia would participate in ensuring their happy existence. Russia likewise wanted the allies to guarantee to the inhabitants of the insurgent provinces freedom of religion and security of property, person, and communal existence. Perhaps anticipating the refusal to sign on to a formal declaration, the proposal concluded by explaining that Alexander would be content with an allied statement supporting the justice of Russia's demands and a declaration of neutrality in the event of a Russian-Ottoman war.

In a report to Nesselrode from I9 April/I May 1822, Lieven described ongoing discussions with Castlereagh during which the foreign secretary spelled out Britain's opposition to Russia's proposal for an allied protocol. ${ }^{75}$ While Tatishchev appeared to make progress in Vienna, Lieven continued to complain about the cautiousness of the British government and Castlereagh's preference for informal diplomatic communication. According to the foreign secretary, the British government would not be able to justify before the British public the break in diplomatic relations that Emperor Alexander hoped to see. Such a step would endanger the property of British subjects within the Ottoman Empire and invite violent reprisals, which then could lead to war. No responsible ministry could sanction war in pursuit of an interest not directly relevant to the British nation. ${ }^{76}$ Britain also opposed Russia's insistence that the Porte respond directly to the original ultimatum, arguing instead for the acceptability of other forms 
of communication. Finally, Castlereagh forcefully objected to the demand that the Porte act in concert with Russia to restore order in the Christian provinces of the Ottoman Empire. This would constitute an infringement of sovereignty by making Russia a "co-State" inside Ottoman territory. Indeed, the idea of common measures implied the existence of common rights, which further implied shared sovereignty. Britain's understanding of Russia's obligation to protect the Christian subjects of the Ottoman Empire did not envision immediate or direct protection, but rather rested on the Porte's responsibility to protect its Christian subjects. The creation of a continual guarantee on behalf of the insurgent provinces would be equivalent to a Russian assumption of legislative authority inside the Ottoman Empire. Finally, as a noncontracting power, Britain could not guarantee commitments agreed to by the Russian and Ottoman governments.

Lieven countered that given the Muslim atrocities afflicting the Porte's Christian territories-Russia’s diplomats invariably neglected to mention Greek atrocities-the Russian government did not see how the insurgent provinces could be pacified or future dissension prevented without Russian-Ottoman agreement on the measures to be adopted. In fact, Russian participation in the pacification process would serve the interests of the Ottoman Empire, for only under the protection of an allied guarantee to ensure a happy existence could the Porte's Greek subjects place their future in the hands of the Turkish government. Despite this telling argument, Emperor Alexander understood, and Lieven accepted, that if the Porte refused to accept Russia's demands, allied declarations of support for the Russian position would necessarily conform to the dignity and interests of each individual government. The collective force of these declarations would then guarantee that the Porte fulfilled the obligations agreed to in negotiations with Russia. Within these limits, moreover, the Divan would be compelled to choose between formal repudiation by the allies and their good offices. To sustain this conclusion in the interest of a united alliance, Russia's diplomats had no choice but to engage in wishful thinking.

The British government remained eager to end the Russian-Ottoman crisis and therefore encouraged Emperor Alexander to treat the four points of the ultimatum as the goal of, rather than the precondition for, negotiations. To suppress the insurrection and to secure Russia's treaty rights and obligations on behalf of the rebellious Greeks, the Russian and Ottoman empires first needed to reestablish diplomatic relations. As things stood, Russia's four demands represented a path to war. Although established treaties supported the Russian conditions, the Porte would never agree to them. Russia, for its part, would not abandon the four points or the Greek people. Before relations with the Porte 
could be restored, the Russian monarch wanted assurances that the insurrection would end-assurances that required the Porte to change course. Castlereagh applauded Alexander's good intentions, commitment to the general cause of peace, and solicitude for the happy future of the Greek nation, but the British government could not support a formal guarantee for the Christian provinces of the Ottoman Empire. In an official memorandum submitted to Lieven, Britain did agree to support Russia's four demands, if the Russian government pledged to restore diplomatic relations once the Porte accepted them and removed Ottoman troops from the principalities. ${ }^{77}$ In the end, Lieven and Castlereagh both recognized that while their governments shared a common goal, they disagreed on how to achieve it. Once again, moreover, as in the case of Naples, Russia did not interpret the disagreements as a threat to a united alliance.

Despite ongoing differences among the great powers, the fruits of the alliance's adaptability became visible by May 1822, when Ottoman troops began to leave the principalities and Russia's diplomats could report evidence of the Porte's willingness to compromise, including the nomination of hospodars. In a letter to Britain's ambassador in Saint Petersburg, Charles Bagot, Nesselrode wrote that evacuation of the principalities would demonstrate the Porte's intention to abide by existing treaties. This would open the door to the first act of peace, the sending of plenipotentiaries to discuss the bases for restoring Russian-Ottoman relations. ${ }^{78}$ In a rescript of 14/26 May, Emperor Alexander congratulated Tatishchev on the success of his earlier mission and ordered him back to Vienna as part of the ongoing allied effort to persuade the Porte to fulfill Russia's demands. Alexander had decided against military action, but he retained the right to reconsider. Over the next few months he continued to expect allied diplomacy, now entrusted to the British ambassador in Constantinople, Lord Strangford, to press for humane treatment of the Greeks and the restoration of hospodar administration in the principalities. ${ }^{79}$ War had been averted, because both Austria and Britain had committed to pressuring the Porte to satisfy Russia's just demands. But the deeper conflict had not been resolved. ${ }^{80}$ Only after complete evacuation of the principalities and the restoration of free navigation in the Black Sea and the straits would Alexander be prepared to reestablish diplomatic relations with the Porte. During conferences of allied plenipotentiaries that began in Vienna at the end of June, the Russian monarch kept open the possibility of war. As the meetings continued in July, he held fast to the idea of joint action should the Porte reject allied demands. The Russian government doubted the Porte's good intentions, which meant that the call for concerted action did not recede. 
As early as February 1822, Russian military commanders had begun to develop war plans in case negotiations with the Ottoman Empire failed. ${ }^{81}$ By September most Ottoman troops had been withdrawn from Moldavia and Wallachia, and the sultan had nominated new hospodars, or governors. The hospodars came from indigenous boyars and princes rather than Phanariot Greeks; however, the Porte had not consulted the Russian government about the appointments. ${ }^{82}$ From Constantinople Lord Strangford also reported that at conferences with the Ottoman minister of foreign affairs (the reis efendi) held on 27 August, the Divan, the council of state presided over by the grand vizier, had formally rejected Russia's proposal for a meeting of plenipotentiaries, declaring that there could be no role for the allies in the pacification of Greece. ${ }^{83}$ In a letter to Strangford, Prince Metternich confirmed the allies' understanding that all four conditions had to be met before the Russian monarch would restore diplomatic relations with the Porte. The Ottoman government continued to challenge the allies by insisting that it had carried out the first three demands of the Russian ultimatum: the reconstruction of churches, protection of the Orthodox religion, and recognition of the distinction between the innocent and the culpable. In reality, only in Constantinople had protection for the Greek religion been restored. Nor had the military evacuation of the principalities been completed. Lord Strangford's proposal that the Porte communicate directly with Saint Petersburg concerning the appointment of the hospodars also had been ignored. As the reis effendi explained, although in the past Emperor Alexander's minister in Constantinople had been informed of the nominations, such action could not occur in the absence of diplomatic relations. ${ }^{84}$

A clear statement of Russia's position on the restoration of diplomatic relations with the Porte, approved by Alexander on 9/2I September 1822, appeared in the formal record of the allied conferences that opened in Verona on 20 October (NS). ${ }^{85}$ With respect to Russian-Ottoman relations, Alexander's decision not to go to war already had been made, and allied negotiations with the Porte were ongoing. The discussions in Verona, like those in Laibach, can therefore be described as a staging of the European alliance. During eighteen months of discussions with the Porte, the Russian statement began, Emperor Alexander had declared his peaceful intentions. ${ }^{86}$ Nor had he tried to augment Russian influence. To the contrary, he wanted only to return to the conditions that had existed before the insurrections in Greece, including recognition of Russia's treaty rights and other political and commercial advantages. In actuality, the parameters of Russia's demands had broadened. Before diplomatic relations with the Porte could be restored, three conditions had to be met. First, direct 
negotiations between plenipotentiaries of the allies, the Porte, and Russia had to be organized to discuss the pacification of Greece (not just Moldavia and Wallachia). The purpose of these negotiations would be to provide guarantees for the Greeks who once again would submit to Ottoman sovereignty. Through concrete action, the Porte would need to demonstrate respect for "the religion that the letter of the treaties placed under the protection of Russia." In other words, the bases for peace in Greece had to satisfy Russia's concern for the fate of its coreligionists by ensuring their happiness and security. Second, with regard to the principalities of Moldavia and Wallachia, Russia expected to receive direct notification of Ottoman plans to complete the military evacuation and nominate hospodars. ${ }^{87}$ Once these steps were taken, Russian consuls could return to the principalities as official verifiers (commissaires vérificateurs) to confirm that the measures adopted by the Porte and hospodars conformed to the treaties and repaired the damage caused by the military occupation. Finally, free trade in the Black Sea had to be restored. Greek merchants flying the Russian flag handled Russia's grain trade, which for the past year had suffered disruptions. ${ }^{88}$ To restore free navigation, the Porte could allow Portuguese, Sardinian, Sicilian, Spanish, and other ships to pass through the straits, or it could respect the flags flown by these vessels. The Russian statement concluded by forcefully proclaiming that the allies had accepted the justice of Emperor Alexander's conditions.

A second statement of Russian policy, contained in a note of $14 / 26$ September 1822 , was submitted to the plenipotentiaries of Austria, Britain, France, and Prussia. ${ }^{89}$ Included also in the acts of the Verona conferences, this note can be read as a preliminary version of the declaration of 28 October/9 November, which the allies would formally approve and which embodied the success of concert diplomacy in preventing war between the Russian and Ottoman empires. Comparison of these documents illustrates Emperor Alexander's ongoing willingness to modify, moderate, and even obscure Russia's demands in order to give allied diplomacy a chance to work, a tactic he had pursued since the fall of $182 \mathrm{I}$. But the monarch also had reviewed the diplomatic communications produced during eighteen months of negotiations in Constantinople and had come to the painful conclusion that no progress had been made. Not only did the Porte refuse to satisfy Russia's just demands; in recent conferences with the British ambassador, Ottoman officials falsely accused the Russian government of supporting the Greek insurrections, and they claimed that all treaty obligations to Russia had been fulfilled. To counter this characterization, the Russian note described the Greek uprisings as the work of the same sects that had triumphed in Spain and Portugal, achieved temporary victories in Italy, and remained an 
ongoing threat to other states in Europe. Russia denied any role in fomenting or supporting revolt in Greece and insisted that the Porte, which had not fully evacuated the Danubian Principalities or agreed to send plenipotentiaries to negotiate with the allies, remained in violation of recognized treaty obligations.

The facts set forth in the Russian note aimed to disprove the Porte's accusations. First, Russia had joined the allies to combat revolution in Naples and Piedmont. Second, Russian foreign policy invariably followed the same rules. Third, there existed in Europe a vast conspiracy directed against the security of thrones and the happiness of peoples. If subaltern agents of the Russian Empire supported revolution in Greece, they acted against the monarch's explicit orders. The Russian government had been waiting a year for the Porte to answer Emperor Alexander's demands, and during this period, despite the absence of insurgency in the principalities, Ottoman forces continued to destroy religious sanctuaries and towns. Commerce in the Russian Empire's southern provinces also remained in a state of paralysis. Indeed, the allies recognized the moderation, frankness, and steadfastness of Russian policy, and they likewise understood that Alexander did not seek to expand Russian influence. Rather, he wished only to secure the political rights and commercial advantages already guaranteed by existing treaties. Precisely because the allies acknowledged Russia's just demands, Alexander had entrusted negotiations concerning the restoration of relations with the Ottoman Empire to Austrian and British diplomats.

With one significant exception, the statements of Russia's conditions for restoring relations with the Porte were identical in the note of $14 / 26$ September and the subsequent declaration of 28 October/9 November..$^{90}$ The first condition relevant to the pacification of Greece appeared in the same form in both documents. In one scenario, the Porte would negotiate with allied and Russian plenipotentiaries concerning guarantees for Greeks who returned to living under the Ottoman sultan's authority. In an alternative scenario, the Porte would demonstrate through concrete measures respect for the Christian religion, which existing treaties placed under Russian protection. In addition, the Porte's actions should exhibit a desire to restore domestic tranquility to Greece on grounds that ensured peace and satisfied Russia's concerns about the fate of its coreligionists. The second condition, which addressed the situation in Moldavia and Wallachia, contained wording in the September note that did not appear in the November declaration. The Porte would notify Russia about the military evacuation of the principalities and the nomination of hospodars. Russian agents would then return to the territories to exercise the rights granted by the treaties and to verify that the steps taken by the Porte and the new princes met treaty 
obligations. Removed from the November declaration was the demand to repair damage caused by the Ottoman military occupation, wording that implicitly challenged the sultan's sovereignty in the Danubian Principalities. Finally, the third condition called for the restoration of free commercial navigation in the Black Sea, where the Porte could permit the passage of Portuguese, Sicilian, Spanish, and other vessels, or respect ships flying the flag of navies previously allowed in these waters.

The official declaration of Russia's position on the affairs of the East, read by Dmitrii Tatishchev at the conferences of 28 October/9 November, received approval in individual allied responses of 22 November (NS). ${ }^{91}$ In addition to the modified conditions for restoring relations with the Porte, the declaration also contained a full summary of developments since the summer conferences in Vienna, where allied plenipotentiaries had accepted Russia's demands as just, based on a communication from Metternich dated 3I July. At a conference on 26 July in Constantinople, Ottoman ministers had accused Russia of hostile intentions and of trying to interfere in the internal affairs of the Ottoman Empire. But during this time, the Porte continued to violate treaty obligations. Ottoman troops remained in the principalities, and attacks on Christianity persisted, including the destruction of Jassy. For the past year, under the auspices of the allies, Russia had pursued the best means to restore peace in the Christian provinces of the Ottoman Empire. Nor had Russia acted against Ottoman interests. Yet the Porte still refused all reciprocity, including a meeting of plenipotentiaries, and continued to restrict Russian commercial navigation in the Black Sea. Finally, at a conference of 27 August, the Ottoman government again had accused Russia of complicity in the disastrous Greek uprisings, which in reality represented the work of the same revolutionary sects that had infected Spain, Portugal, and Italy. The Porte, it seemed, had forgotten the diplomatic overtures of Baron Stroganov and the fact that Emperor Alexander had ordered his troops to march against revolutionaries in Naples and Piedmont. Despite the mutual recriminations, in November 1822, the Russian monarch stood by his offer to act with the allies to restore peace in Greece.

On $15 / 27$ November, during the conferences in Verona, Tatishchev could declare that his sovereign was satisfied with allied promises to take additional steps through their ambassadors in Constantinople to pressure the Porte to accept Russia's conditions for the restoration of diplomatic relations. The European alliance, directed by the five great powers, once again appeared fully united, as Austria, Britain, France, and Prussia all accepted the Russian declaration of 9 November. ${ }^{92}$ Another declaration, approved by Alexander on 16/28 November, 
acknowledged the allies' response. ${ }^{93}$ The allies appreciated the sacrifices Russia had made for peace in Europe and intended to continue their efforts to persuade the Porte to accept Russia's just and moderate conditions. For the moment, Emperor Alexander had decided to act in concert with the great powers to resolve the Greek crisis and to convince the Porte of the need for amicable intervention by the European allies. Through the conferences established in Vienna, the monarch would continue to rely on allied diplomacy to conduct negotiations in Constantinople. Based on the Verona declarations, it appeared that Alexander would not insist on bilateral negotiations between Saint Petersburg and Constantinople to decide matters concerning the principalities or Russia's recognized treaty rights. On 20 November, the allies meeting in Verona agreed not to sign a general protocol, and on 3/15 December, Emperor Alexander departed the conferences. ${ }^{94}$

If the diplomacy surrounding the war scare of $182 \mathrm{I}-22$ revealed an effective European system capable of containing great power competition to ensure peace, this was not the result of shared governance or a collective security regime defined by recognized legal principles and administrative procedures. Between I8I 4 and the outbreak of the Crimean War in 1853 successful peacemaking evolved from the flexibility of the grand alliance and the ideal of unity that inspired the monarchs and diplomats of Europe. ${ }^{95}$ From the Russian perspective, memories of the Napoleonic Wars, particularly the trauma of I812, reinforced the belief that only through allied unity and the prevention of particular combinations among the great powers could peace be preserved. Emperor Alexander's desire for peace could not have been more powerful. It was so powerful, in fact, that it eclipsed long-standing strategic, economic, and political interests. The realization of Catherine II's plans for territorial aggrandizement and the restoration of a Christian monarchy in Constantinople-as recently as I8I2 Russia had acquired Bessarabia from the Ottoman Empire-had been temporarily set aside. Thus, during the war scare of $182 \mathrm{I}-22$, the concert of great powers did not group, contain, or constrain Russia. Alexander I remained committed to allied unity and continued to rely on friendship among the sovereigns to preserve peace. Equally important, he opted for peace only after the European powers recognized the Russian Empire's legitimate demands and right to act. ${ }^{96}$ Because of the moral support given to Russia, and the commitment to collective negotiations, represented here by the actions of Austria and Britain, the monarch decided to give diplomacy a chance.

Not surprisingly, the subsequent history of the Greek independence movement exposed fundamental fissures in the much-touted European system. By 
February 1824, diplomatic relations between the Russian and Ottoman empires had been partially restored. Still, allied conferences held in Saint Petersburg in June I824 and March I825 failed to produce a common policy toward Greece. In a memorandum of 9/21 January 1824, Emperor Alexander had proposed the creation of three semiautonomous principalities under Ottoman suzerainty, an arrangement modeled on political arrangements in the Danubian Principalities and Serbia. The response had been disappointing. Austria and Prussia showed no interest in supporting the claims of Greek rebels against their legitimate sovereign. British officials, the Ottoman sultan, and Greek leaders also refused to discuss the proposal. In the summer of I825, Russia once again seemed headed toward unilateral action against the Porte. Even the cautious Count Nesselrode adopted a pro-war position, and Alexander, dissatisfied with Strangford's continuing mediation between Russia and the Porte, ended allied negotiations in late July. In December the Russian monarch died, and uncertainties surrounding the succession allowed the empire's first modern political opposition, led by elite military officers, briefly to attempt revolution.

After a temporary pause, diplomatic efforts to address the Greek crisis and Russian-Ottoman disputes resumed in 1826 . Britain and Russia signed the Saint Petersburg Protocol, adopting a Greek request for mediation. ${ }^{97}$ In October 1826 the Porte accepted the Convention of Akkerman in response to an ultimatum from Emperor Nicholas I, who continued to express disdain for the Greek rebels. The convention affirmed the obligation to implement Russian-Ottoman treaty provisions and to remove the last Ottoman troops from the Danubian Principalities. Parallel to these developments, the European powers continued the effort to negotiate a common policy. Finally, on 6 July I827, Britain, France, and Russia agreed to the Treaty of London, which called for the establishment of an autonomous Greek state under Ottoman suzerainty. The signatories rejected participation in Greek-Ottoman hostilities, though based on a secret article, they agreed to force the Greeks and Ottomans to accept an armistice. Not surprisingly, the Porte continued to reject allied mediation. On 20 October 1827 , following the establishment of a joint British, French, and Russian blockade to prevent Ottoman arms and troops from reaching Greece (already a violation of the Treaty of London), the allied squadron destroyed the Ottoman fleet in the Bay of Navarino. Then on 30 November, Nicholas withdrew from Akkerman. In December the sultan followed suit, vowing also to fight Russia to protect his empire. This step produced a formal break in diplomatic relations with Britain, France, and Russia, based on the Treaty of London. Full-scale war between the Russian and Ottoman empires began in April I828, with no allied participation 
or support for Russia. The allies did, however, provide military, naval, and financial assistance to the Greek government. Finally, on 22 March 1829, the Porte agreed to Greek autonomy, and on 3 February 1830 , the London Protocol established Greece as an independent monarchy. ${ }^{98}$

\section{Unity amid Divergence}

During the years from 1820 through 1822, Europe's peacemakers responded to insurrections in Spanish America, Spain, the Kingdom of the Two Sicilies, Portugal, Piedmont, and Greece by focusing on questions of legality, reform, and revolution. As in earlier discussions about conditions in France and Germany, in the negotiations about possible intervention in Spain and the Two Sicilies, Russian policymakers, instructed by Emperor Alexander I, continued to proclaim the need for good governance and political reform, including even constitutional reform, to prevent rebellion and preserve peace. But although reform could appear both desirable and necessary, the overthrow of legitimate rulers could not be tolerated, even when popular disaffection seemed justified. The allies remained united on this principle, and although Britain and France did not officially participate in the Troppau and Laibach conferences, they did not openly oppose collective action by the other great powers. Perhaps more revealing, when revolutionary situations directly impacted British and French interests, as in Greece and Spain, they actively embraced the commitment to act in concert. Throughout the period from the Congress of Vienna (1814-15) until the French intervention in Spain (1823), all the principals among the great powers viewed revolution as a scourge, and all agreed that the scourge had infected much of Europe.

The Greek crisis and Russian-Ottoman war scare of I82I-22 exposed challenges to the eternal principles of European peace-challenges that arose from developments beyond the confines of Europe. At the same time, events on the ground and ongoing allied negotiations also highlighted the limits to Emperor Alexander's enlightened vision of European unity. Based on documents of Russian provenance, the monarch's moderation and commitment to legality appeared genuine, illustrated by the rift with Kapodistrias and the insistence that Stroganov be prevented from encouraging war and spreading extremist views in Saint Petersburg society. ${ }^{99}$ But in relations with the allies, the pressure to address political arrangements and questions of stability within the Ottoman Empire also brought to the fore long-standing suspicions about Russian objectives. Nor did the allies satisfy Alexander's expectations of what it meant to act in concert, 
based on the legal obligations and moral duties codified in alliance treaties. Even so, despite repeated disappointments embodied in the decisions of Troppau, Laibach, and Verona, allied unity held.

Russia had a long history of diplomatic and military entanglements with the Ottoman Empire. The war scare of $182 \mathrm{I}-22$ at once endangered the peace established by the Treaty of Bucharest (1812) and represented a successful effort to defuse a major crisis within the framework of the European system. Alexander expected the allies to recognize Russia's legal rights, including the right to protect Christians living under Ottoman authority and the right to use military force to compel compliance with treaty obligations. These expectations, according to Russia's policymakers, were consistent with Prussian and Russian support for Austria's intervention in Naples and with Alexander's offer of military assistance to France, if Spanish revolutionaries tried to move into French territory. Finally, the Russian-Ottoman war scare showed that Emperor Alexander's idea of European unity could not be separated from Christian beliefs, which inside and outside of Europe, and certainly within the Russian Empire, undermined ideals of enlightened universalism and religious toleration. Both the Treaty of 14/26 September i815 (the Holy Alliance) and Baron Stroganov's note to the Porte of 6/18 July I82I proclaimed the idea of religious coexistence in Europe's relations with the Ottoman Empire. Yet the crisis of I82I-22 exposed ongoing religious and nationalist excesses: anti-Greek, anti-Turk, anti-Christian, and anti-Muslim. As toleration and cosmopolitanism degenerated into religious and national strife, the potential for total war, already evident in the French Revolutionary and Napoleonic Wars, reemerged. ${ }^{100}$ Moderate reformism, which embraced legal-administrative (and even constitutional) change without violence against established order, would be tested over and over again. 